\title{
All-Solid-State Lithium Battery Working without an Additional Separator in a Polymeric Electrolyte
}

\author{
Seonggyu Cho ${ }^{1,2}$, Shinho Kim ${ }^{1}$, Wonho Kim ${ }^{2}$, Seok Kim ${ }^{2}$ and Sungsook Ahn ${ }^{1,3, *(\mathbb{D})}$ \\ 1 Secondary Battery R\&D Center, DRB Holdings Co., Pusan 46329, Korea; \\ cho.seong.gyu@drbworld.com (S.C.); kim.shin.ho@drbworld.com (S.K.) \\ 2 Department of Chemical and Biochemical Engineering, Pusan National University, Pusan 46241, Korea; \\ whkim@pnu.edu (W.K.); seokkim@pusan.ac.kr (S.K.) \\ 3 Department of Mechanical Engineering, Pohang University of Science and Technology (POSTECH), \\ Pohang 37673, Korea \\ * Correspondence: sungsookahn@yahoo.com
}

Received: 1 October 2018; Accepted: 1 December 2018; Published: 9 December 2018

\begin{abstract}
Considering the safety issues of Li ion batteries, an all-solid-state polymer electrolyte has been one of the promising solutions. Achieving a Li ion conductivity of a solid-state electrolyte comparable to that of a liquid electrolyte $(>1 \mathrm{mS} / \mathrm{cm})$ is particularly challenging. Even with characteristic ion conductivity, employment of a polyethylene oxide (PEO) solid electrolyte has not been sufficient due to high crystallinity. In this study, hybrid solid electrolyte (HSE) systems have been designed with $\mathrm{Li}_{1.3} \mathrm{Al}_{0.3} \mathrm{Ti}_{0.7}\left(\mathrm{PO}_{4}\right)_{3}$ (LATP), $\mathrm{PEO}$ and lithium bis(trifluoromethanesulfonyl)imide (LiTFSI). A hybrid solid cathode (HSC) is also designed using LATP, PEO and lithium cobalt oxide $\left(\mathrm{LiCoO}_{2}, \mathrm{LCO}\right)$-lithium manganese oxide $\left(\mathrm{LiMn}_{2} \mathrm{O}_{4}, \mathrm{LMO}\right)$. The designed HSE system has $2.0 \times 10^{-4} \mathrm{~S} / \mathrm{cm}\left(23^{\circ} \mathrm{C}\right)$ and $1.6 \times 10^{-3} \mathrm{~S} / \mathrm{cm}\left(55^{\circ} \mathrm{C}\right)$ with a $6.0 \mathrm{~V}$ electrochemical stability without an additional separator membrane introduction. In these systems, succinonitrile (SN) has been incorporated as a plasticizer to reduce crystallinity of $\mathrm{PEO}$ for practical all-solid Li battery system development. The designed HSC/HSE/Li metal cell in this study operates without any leakage and short-circuits even under the broken cell condition. The designed HSC/HSE/Li metal cell in this study displays an initial charge capacity of $82 / 62 \mathrm{mAh} / \mathrm{g}\left(23^{\circ} \mathrm{C}\right)$ and $123.4 / 102.7 \mathrm{mAh} / \mathrm{g}\left(55^{\circ} \mathrm{C}\right)$. The developed system overcomes typical disadvantages of internal resistance induced by $\mathrm{Ti}$ ion reduction. This study contributes to a new technology development of all-solid-state Li battery for commercial product design.
\end{abstract}

Keywords: secondary Li ion battery; all-solid-state battery; solid polymer electrolyte; succinonitrile (SN); lithium(trifluoromethanesulfonyl)imide (LiTFSI)

\section{Introduction}

$\mathrm{Li}$ ion batteries have been credited for a great revolution of the strong intermittent renewable-energy sources replacing fossil fuels. They also critically contribute to the development of communication and transportation by the rise of super-slim smart phones and electric cars in a practical range. However, since announced in 1991, heels of Li ion battery phones and laptops have been recalled because of a flame causing injury to the users [1]. The cycle life is limited because of poor cycling efficiency of Li electrode. The secondary cells are more sensitive to impurities such as water in the electrolyte and the electrode materials. In addition, the cells under running would have Li dendrites leading to occasional explosions. Nonetheless, because of radical needs for high energy density and reliability of batteries, Li technology has been ceaselessly focused on. With high energy 
density and large capacity suitable for energy storage systems, Li ion is almost unique among all other negative electrode materials that have ever been investigated.

The typical $\mathrm{Li}$ ion batteries consist of a negative anode, a positive cathode and a liquid electrolyte. However, many energy storage devices based on combustible organic solvents inevitably carry the risks of leakage, heavier packaging and related hazards. A liquid electrolyte is volatile at high temperature when the battery is charged or discharged quickly or packs of car batteries are damaged in accidents. Against inherent disadvantages of liquid electrolytes [2,3], solid electrolytes of nonflammable polymers [4,5] and all-solid-state batteries using inorganic materials $[6,7]$ have been developed. When a battery releases power, Li ions move from the anode through the electrolyte to the cathode. In this point, more conductive electrolyte generates better battery performance. Therefore, the promise of $\mathrm{Li}$ ion solid-state batteries is the replacement of the heavy and sometimes dangerous liquid electrolyte with lighter, more versatile and solid alternatives. Although finding a solid electrolyte with conductivity comparable to liquids has been still a challenge, the solid electrolyte batteries are popular. They are safer because flammable components are removed and deliver more power by replacing the carbon-based anodes with Li metal. This leads to a higher energy density and cycle life with less weight and cost. In addition, without a need to struggle to safely pack a liquid electrolyte in a shape, all-solid-state batteries can be fabricated in more versatile shapes, reducing manufacturing costs. This could make electric cars a more enticing proposition with longer running distance and a lower purchase price. In many ways, all-solid-state constructions certainly enhance the overall performance of energy storage and conversion [8-14].

A potential solution against the disadvantage of solid-state electrolytes has been pursued in this point [15-19]. The conductivity of polymer electrolytes such as polyethylene oxide (PEO) has been utilized [20-23], which is considered by the electron donating activity, coordinate bonding and hopping of Li ions [24]. As other electrolytes, alkali crystalline complexes of PEO with metals have also been investigated with prominent ion conductivity [25-28]. However, the Li agent in PEO is not sufficient to generate effective ionic conductivity because high crystallinity of PEO impairs Li ion movement. The amorphous sites of PEO contribute to enhance the Li ion movement especially at room temperature [29-32]. When the PEO complex with relatively low glass transition temperature $\left(T_{\mathrm{g}}\right)$ becomes amorphous, the ion conductivity is $10^{-5}-10^{-4} \mathrm{~S} / \mathrm{cm}$, corresponding to 3-4 times higher than those of crystallite counterparts. However, the PEO complex displays a liquid-like property, which simultaneously induces short-circuits, the typical disadvantages of liquids.

\subsection{Oxide Solid Electrolytes}

Inorganic oxides have been designed for electrolyte components [33-36], such as Perovskite-structured $\mathrm{Li}_{3 x} \mathrm{La}_{2 / 3-x} \mathrm{TiO}_{3}$ [33], Garnet-structured $\mathrm{Li}_{7} \mathrm{La}_{3} \mathrm{Zr}_{2} \mathrm{O}_{12}$ (LLZO) [34,35], NASICON-structured $\mathrm{Li}_{1.3} \mathrm{Al}_{0.3} \mathrm{Ti}_{0.7}\left(\mathrm{PO}_{4}\right)_{3}$ (LATP) [36]. Nonetheless, low conductivity, high grain boundary resistance and high calcination temperature of these oxide solid electrolytes cause increased volatility, phase transition and impurity, decreasing the total quality of Li ion battery. On the other hand, sulfide-based solid electrolyte including $\mathrm{Li}_{10} \mathrm{GeP}_{2} \mathrm{~S}_{12}$ (LGPS) display high conductivity almost similar to that of liquid electrolytes [37]. However, it is smelly, expensive, unstable under air and reactive with water, generating harmful $\mathrm{H}_{2} \mathrm{~S}$. A battery system composed of lithium aluminum germanium phosphate (LAGP, $\mathrm{Li}_{1.5} \mathrm{Al}_{0.5} \mathrm{Ge}_{1.5}\left(\mathrm{PO}_{4}\right)_{3}$ ), and $\mathrm{PEO}$ has been tried with protecting layers [38]. In addition, it works at around $50{ }^{\circ} \mathrm{C}$ but not at lower room temperature. One of the oxide solid electrolytes, lithium aluminum titanium phosphate (LATP), is highly stable under air and is inexpensive. However, LATP exhibits lower ion conductivity than liquid electrolytes or sulfide-based electrolytes, reduction of $\mathrm{Ti}^{4+}$ into $\mathrm{Ti}^{3+}$ by the interaction of $\mathrm{Li}$ ion, and high grain boundary resistance. In addition, the lattice structure of solid electrolytes modified by Ti ion reduction affects the $\mathrm{Li}$ ion movement. The complex composed of $\mathrm{Ti}^{4+}$ typically generates a conductivity close to $10^{-3} \mathrm{~S} / \mathrm{cm}$ while that of $\mathrm{Ti}^{3+}$ significantly decreases the conductivity to $10^{-7} \mathrm{~S} / \mathrm{cm}$ [39]. To overcome these problems, protecting thin layers composed of $\mathrm{PEO}$ or $\mathrm{Al}_{2} \mathrm{O}_{3}$ has been introduced to minimize the interaction with 
$\mathrm{Li}$ ion $[38,40]$. An LATP pellet was dip-coated by PEO for a protecting layer formation between the LATP and Li metal surface where the whole system can exhibit ionic conductivity of $5.03 \times 10^{-6} \mathrm{~S} / \mathrm{cm}$ at $23{ }^{\circ} \mathrm{C}$ [41]. In this study, new battery systems are designed without protecting layer introduction, which also effectively work at room temperature.

\subsection{Succinonitrile (SN) Introduction}

Lithium bis(trifluoromethanesulfonyl)imide (LiTFSI) exhibits limitation in narrow electrochemical windows $(\sim 4.8 \mathrm{~V})$ and low electrochemical stability. To overcome these disadvantages, nonionic polymeric crystalline with excellent electrochemical stability is obtained by using succinonitrile (SN) $[42,43]$. Nitrile compounds are typically safe against fire and chemically stable under harsh conditions. SN has a $T_{\mathrm{g}}$ of $-40{ }^{\circ} \mathrm{C}$ and a melting temperature $\left(T_{\mathrm{m}}\right)$ of $55{ }^{\circ} \mathrm{C}$. Between these temperatures, $\mathrm{SN}$ suppresses the crystallization of $\mathrm{PEO}$ and increases the physical stability against short-circuit. In addition, $\mathrm{SN}$ is highly polar to enhance the Li dissolution and movement. When SN forms a complex with LiTFSI, the conductivity increases up to $1 \times 10^{-3} \mathrm{~S} / \mathrm{cm}\left(25^{\circ} \mathrm{C}\right)$ due to molecular rotation and trans-gauche isomerism [44,45]. Even though LGPS is relatively expensive and reactive with water, generating unfavorable $\mathrm{H}_{2} \mathrm{~S}$ [46], an LGPS+PEO+SN hybrid system does not affect $\mathrm{Li}$ ion movement due to SN contribution [43]. The chemical reactivity of Li ions with LATP determines the ionic conductivity, but this has not been fully investigated for LATP+PEO+SN hybrid systems, and there is a lack of systematic electrochemical analysis to verify the interaction with $\mathrm{Li}$ ions.

In this study, all-solid-state Li ion batteries using designed hybrid solid electrolytes (HSEs) are investigated to overcome the typical disadvantages of PEO-based Li ion battery systems. Compromising the properties of LATP by overcoming the disadvantageous grain boundary resistance by $\mathrm{PEO}$ introduction, $\mathrm{SN}$ is utilized for increased mechanical property and reduced possibility of short-circuits. Ion conductivity is prominently enhanced at room temperature by using effective dissolution of an SN complex with LiTFSI and PEO. The chemical reaction is monitored by the day-by-day changes in impedance considering the physical interaction of LATP and Li metal. The reduction of Ti ion is investigated by using X-ray photoelectron spectroscopy (XPS) after the charging-discharging repetition. Linear scanning voltammetry (LSV) curves of the designed electrodes confirm the extended region of electrochemical windows of PEO-only system which is originally narrow, near $4.8 \mathrm{~V}$.

\section{Experimental Section}

\subsection{Chemicals}

All chemicals were purchased and used without further purification: Conductive carbon black (TIMCAL Graphite \& Carbon Super $\mathrm{P}^{\circledR}$ Conductive Carbon Black, MTI Corporation, Richmond, CA, USA), $\mathrm{Li}_{2} \mathrm{CO}_{3}$ (lithium carbonate, 99\%, Sigma-Aldrich, St. Louis, MO, USA), $\mathrm{Al}_{2} \mathrm{O}_{3}$ (aluminum oxide, 99.99\%, Sigma-Aldrich, St. Louis, $\mathrm{MO}, \mathrm{USA}$ ), $\mathrm{TiO}_{2}$ (Cotiox KA-100, 98\%, Cosmo Chemical, Incheon, Korea), $\mathrm{NH}_{4} \mathrm{H}_{2} \mathrm{PO}_{4}$ (ammonium dihydrogenphosphate, 99.999\%, Sigma-Aldrich, St. Louis, MO, USA), PEO (polyethylene oxide, $M_{\mathrm{W}}=1 \times 10^{5}, 3 \times 10^{5}$ and $6 \times 10^{5}$, Sigma-Aldrich, St. Louis, MO, USA), LiTFSI (bis(trifluoromethane) sulfonimide lithium salt, 99.95\%, Sigma-Aldrich, St. Louis, MO, USA), $\mathrm{LiPF}_{6}$ (lithium hexafluorophosphate, 99.99\%, Sigma-Aldrich, St.Louis, MO, USA), AN (acetonitrile anhydrous, 99.8\%, Sigma-Aldrich, St. Louis, MO, USA), SN (succinonitrile, 99\%, Sigma-Aldrich, St. Louis, MO, USA), LCO (PoscoESM, Gumi, Korea), LMO (G05, ILJIN materials, Seoul, Korea).

\subsection{Synthesis of LATP}

The solid electrolyte LATP $\left(\mathrm{Li}_{1.3} \mathrm{Al}_{0.3} \mathrm{Ti}_{0.7}\left(\mathrm{PO}_{4}\right)_{3}\right)$ is synthesized by a conventional solid-state method. Stoichiometric amounts of $\mathrm{Li}_{2} \mathrm{CO}_{3}, \mathrm{Al}_{2} \mathrm{O}_{3}, \mathrm{TiO}_{2}$, and $\left(\mathrm{NH}_{4}\right) \mathrm{H}_{2} \mathrm{PO}_{4}$ are mixed in a ball mill for $12 \mathrm{~h}$. The slurry is sintered in a furnace at $900{ }^{\circ} \mathrm{C}$ for $2 \mathrm{~h}$. The dried powder is then jet milled at $1800 \mathrm{rpm}$ for $2 \mathrm{~h}$ to reduce the particle size. D-values $\left(\mathrm{D}_{10}, \mathrm{D}_{50} \& \mathrm{D}_{90}\right)$ are measured for particle size 
evaluation as an intercept for $10 \%, 50 \%$ and $90 \%$ of the cumulative mass and $D_{50} \sim 6 \mu \mathrm{m}$ is obtained for effective mixing process.

\subsection{Preparation of Hybrid Solid Electrolytes (HSE) and Hybrid Solid Electrolyte Cathode (HSC)}

The Li ion conducting polymer PEO is mixed with LiTFSI ([EO]:[Li] = 8:1) and previously synthesized LATP (LATP:PEO = 8:2 by weight) in acetonitrile (AN). The polymer solution is mixed using a centrifugal mixer (THINKY mixer ARM-310, Oxfordshire, UK) at $2000 \mathrm{rpm}$ for $15 \mathrm{~min}$, with or without $5 \mathrm{wt} \%$ of SN (Succinonitrile). The slurry is mixed again for $15 \mathrm{~min}$. For the tests, this HSE slurry is casted on $\mathrm{Al}$ foil for analysis or on an electrode for coin cell test. After natural drying at room temperature for $1 \mathrm{~h}$, samples are dried completely in a $50{ }^{\circ} \mathrm{C}$ vacuum oven for $12 \mathrm{~h}$.

For better binding in the electrode, higher molecular weight PEO $\left(\mathrm{M}_{\mathrm{w}} \sim 3 \times 10^{5}\right.$ and $\left.6 \times 10^{5}\right)$ was employed. LATP, PEO (LATP:PEO = 5:5 by weight) and LiTFSI ([EO]:[Li] $=10: 1$ ) were mixed in AN using THINKY mixer for 15 min. $\mathrm{LiMn}_{2} \mathrm{O}_{4}$ and $\mathrm{LiCoO}_{2}$ as active materials and Super-P as conductive material were added in additional solvent AN, followed by mixing for $15 \mathrm{~min}$. After the HSC slurry was casted on $\mathrm{Al}$ foil by Scalpel, the electrodes were dried at $80^{\circ} \mathrm{C}$ in a vacuum oven for $24 \mathrm{~h}$. HSE slurry was casted on the dried electrode and Li metal. The aforementioned HSE and HSC thickness is designed uniformly at $270 \mu \mathrm{m}$ and $80 \mu \mathrm{m}$ scale and the active material loading of electrodes is designed uniformly at a $10 \mathrm{mg} \mathrm{cm}^{-2}\left( \pm 0.1 \mathrm{mg} \mathrm{cm}^{-2}\right)$ scale. The HSC/HSE composite was dried under the aforementioned condition. Differing from the cathode side, the Li metal/HSE composite was dried at room temperature for $24 \mathrm{~h}$ to prevent crumbling. To evaluate the electrochemical performance, the CR2032 coin-type cell and all-solid-state pouch cell at a $5 \times 10 \mathrm{~cm}^{2}$ scale was fabricated with HSC/HSE composite and Li metal/HSE by a lamination process. The construction of the cell is described as Figure 1. All processes were conducted in a dry-room.
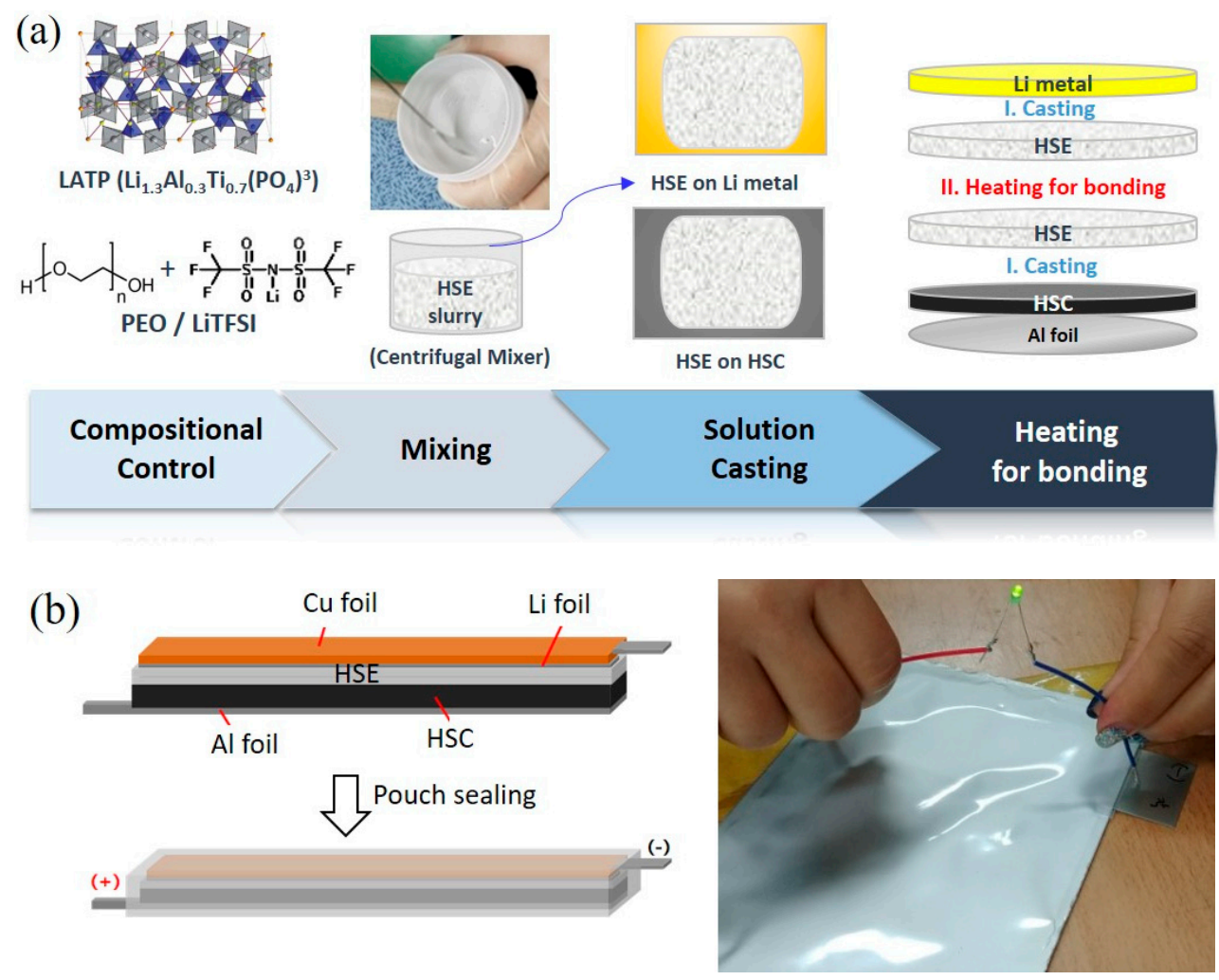

Figure 1. (a) Preparation of all-solid-state coin-cell using the designed HSE and HSC in this study. (b) Configuration of all-solid-state pouch cell at a $5 \times 10 \mathrm{~cm}^{2}$ scale (left scheme) and its operation (right picture). 


\subsection{Characterizations}

Synthesized LATP and the HSC/HSE composites were observed using a scanning electron microscope (SEM, SEC Mini SEM SNE-3000M, Pleasanton, CA, USA) and X-ray diffraction (XRD, Rigaku MiniFlex 600, The Woodlands, TX, USA). XRD patterns of samples were obtained over a $2 \theta$ range from $10 \mathrm{deg}$ to $80 \mathrm{deg}$ with $\mathrm{Cu} \mathrm{K} \alpha$ radiation at room temperature. The scan rate was $6 \mathrm{deg} / \mathrm{min}$. Linear sweep voltammetry (LSV) was performed for both oxidation and reduction procedures for selected samples using a potentiostat (Bio Logic SP-150) with scan rate of $20 \mathrm{mV} / \mathrm{s}$ from OCV to $1.5 \mathrm{~V}$ or $6.0 \mathrm{~V}$. Ionic conductivity is calculated by the AC impedance method with symmetric SS/Al/HSE/ $\mathrm{Al} / \mathrm{SS}$ cell using a multi-channel potentiostat (Bio Logic VMP3, Seyssinet-Pariset, France). The samples were placed at $25^{\circ} \mathrm{C}$ and $55^{\circ} \mathrm{C}$ for $12 \mathrm{~h}$, and then analyzed from $500 \mathrm{kHz}$ to $1 \mathrm{~Hz}$ at open-circuit voltage with $5.0 \mathrm{mV}$ amplitude. With a differential scanning calorimeter (DSC, DISCOVERY DSC 2500, TA Instrument, New Castle, DE, USA), the calorimetric measurement is performed from room temperature to $100{ }^{\circ} \mathrm{C}$ at the heating rate of $10^{\circ} \mathrm{C} / \mathrm{min}$. For each $\mathrm{C}$-rate $\left(1 \mathrm{C}=1.5 \mathrm{~mA} \mathrm{~cm}^{-2}\right)$, the cell was charged using a constant current charge $(0.05 \mathrm{C}$ \& each C-rate) using a charge step from $3.0 \mathrm{~V}$ to $4.3 \mathrm{~V}$, followed by a constant voltage charge at $4.3 \mathrm{~V}$. For discharge, the constant current discharge $(0.05 \mathrm{C} \&$ each $\mathrm{C}$-rate) from $4.3 \mathrm{~V}$ to $3.0 \mathrm{~V}$ was applied at room temperature or $55^{\circ} \mathrm{C}$.

\section{Results}

\subsection{Design of Hybrid Solid Electrolytes (HSE) and Hybrid Solid Cathode (HSC)}

This study introduces a designed hybrid solid electrolyte (HSE) and hybrid solid cathode (HSC). The HSCs are designed by combining lithium manganese oxide $\left(\mathrm{LMO}, \mathrm{LiMn}_{2} \mathrm{O}_{4}\right)$ with lithium cobalt oxide $\left(\mathrm{LCO}, \mathrm{LiCoO}_{2}\right)$. In Table 1 , composition and ion conductivity of the designed HSC and HSE are summarized at two temperature conditions $\left(23\right.$ and $\left.55^{\circ} \mathrm{C}\right)$. $\mathrm{Li}$ ion-conducting PEO is mixed with lithium aluminum titanium phosphates (LATP) synthesized in this study (Experimental Section). This sticky white HSE slurry is casted on $\mathrm{Al}$ or Li metal foil. For better casting process, the viscosity of the slurry is modified by controlling the content of LATP and PEO as well as molecular weight of PEO. The battery efficiency is compared with lithium(trifluoromethanesulfonyl)imide (LiTFSI) and lithium hexafluorophosphate $\left(\mathrm{LiPF}_{6}\right)$. In addition, the function of $\mathrm{SN}$ is evaluated in terms of the interaction with PEO and LiTFSI. Ion conductivity is compared with pure PEO electrolyte (HSE-1) and PEO/LATP (20/80) composite electrolyte with $\mathrm{LiPF}_{6}$ (HSE-2). With LiTFSI, the PEO/LATP (20/80) composite electrolyte without (HSE-3) and with (HSE-4) SN incorporation is compared. Two types of $\mathrm{LMO} / \mathrm{LCO}$ (30/30)-based cathodes are compared containing the PEO/LATP (12.8/12.8) composite combined with LiTFSI, without (HSC-1) and with (HSC-2) SN incorporation.

Table 1. Designed hybrid solid electrolyte (HSE) and hybrid solid cathode (HSC) in this study.

\begin{tabular}{|c|c|c|c|c|c|c|c|c|c|c|}
\hline & & LATP (g) & $\begin{array}{l}\text { PEO * } \\
\text { (g) }\end{array}$ & $\mathrm{LiPF}_{6}$ & LiTFSI & SN (g) & $\begin{array}{c}\mathrm{LMO}+\mathrm{LCO} \\
(\mathrm{g})\end{array}$ & $\begin{array}{c}\text { EO:Li } \\
\text { (Mole ratio) }\end{array}$ & $\begin{array}{c}\text { Ion. Con. } \\
@ 23{ }^{\circ} \mathrm{C} \\
{[\mathrm{S} / \mathrm{cm}]}\end{array}$ & $\begin{array}{c}\text { Ion. Con. } \\
@ 55^{\circ} \mathrm{C} \\
{[\mathrm{S} / \mathrm{cm}]}\end{array}$ \\
\hline \multirow{4}{*}{ HSE } & HSE-1 & - & 100 & $\bullet$ & - & - & - & $8: 1$ & $1.7 \times 10^{-7}$ & - \\
\hline & HSE-2 & 80 & 20 & $\bullet$ & - & - & - & $8: 1$ & $1.2 \times 10^{-4}$ & $2.4 \times 10^{-3}$ \\
\hline & HSE-3 & 80 & 20 & - & $\bullet$ & - & - & $8: 1$ & $1.5 \times 10^{-4}$ & $1.4 \times 10^{-3}$ \\
\hline & HSE-4 & 80 & 20 & - & $\bullet$ & 5 & - & $8: 1$ & $2.0 \times 10^{-4}$ & $1.6 \times 10^{-3}$ \\
\hline \multirow{2}{*}{ HSC } & HSC-1 & 12.8 & 12.8 & - & $\bullet$ & - & $30+30$ & 10:1 & - & - \\
\hline & HSC-2 & 12.8 & 12.8 & - & - & 5 & $30+30$ & 10:1 & - & - \\
\hline
\end{tabular}

The ionic conductivities of HSE at 23 and $55^{\circ} \mathrm{C}$ are shown. ${ }^{*}$ PEO $M_{\mathrm{W}}=6 \times 10^{5} \mathrm{~g} \cdot \mathrm{mol}^{-1}$, is used for HSE-1 to HSE-4, while PEO $M_{\mathrm{W}}=3 \times 10^{5} \mathrm{~g} \cdot \mathrm{mol}^{-1}$ are used for HSC-1 and HSC-2. For the whole battery design, HSE- 1 to HSE-4 are combined with HSC-1, but HSC-2 is only combined with HSE-4.

A representative coin cell preparation using the designed HSE-4 and HSC-2 is illustrated in Figure 1a. The slurry is coated on Li metal foil by solution casting. LATP, PEO, LiTFSI and SN are 
mixed in a designed composition using a centrifugal mixer (Thinky Mixer) resulting in a sticky white HSE-4 slurry. LMO and LCO are mixed with PEO and SN, resulting in HSC-2. The HSC-2 is coated on Al foil, followed by HSE-4 slurry casting. The Li metal anode and the designed cathode plates are bonded by heating HSE sides to form a layered structure of a coin cell. In addition, this process is scaled-up for a pouch cell $\left(5 \times 10 \mathrm{~cm}^{2}\right)$ in which copper foil is additionally employed outside of the Li metal plate for physical protection (Figure 1b). The designed all-solid-state lithium pouch battery is successfully working in spite of its breakage without any leakage and short-circuits (Supporting Information, Movie S1).

\subsection{Structure of the All-Solid-State Battery System}

The simplified battery sample is prepared to investigate the performance of HSE and HSC, which are casted and dried on a layered structure stacked from Al foil, cathode (HSC-2) and electrolyte (HSE-4) layers without anode Li metal and protective $\mathrm{Cu}$ foil layers. A representative scanning electron microscopy (SEM) image of each layer is shown in a cross-sectional side-view (Figure 2a) and in a top-view (Figure 2b). In the cross-sectional image, the size of particulates in HSC layer (below the dotted-line in the picture) is smaller compared with that in the HSE layer; this is caused by the relatively small size of the LCO and LMO particles (Figure 2d). The images of pure LATP powder are compared in Figure 2c. The top-view images of the designed battery system (Figure 2b) are similar to those of the LATP powder pellet (Figure 2c). For all the systems, the inter-particulate spaces are effectively filled with PEO binding. The SEM images confirm effective physical contact of ion-conducting PEO and solid LATP in the designed HSE layer without phase separation, which is crucial for effective ionic conductivity of a battery. Figure $2 b$ depicts the reticulated PEO connects LATP particles forming ion-conducting pathways, which can decrease boundary resistance in the solid LATP electrolyte. All of these morphologies are advantageous for the increase in the bulk ionic conductivity [47-49].

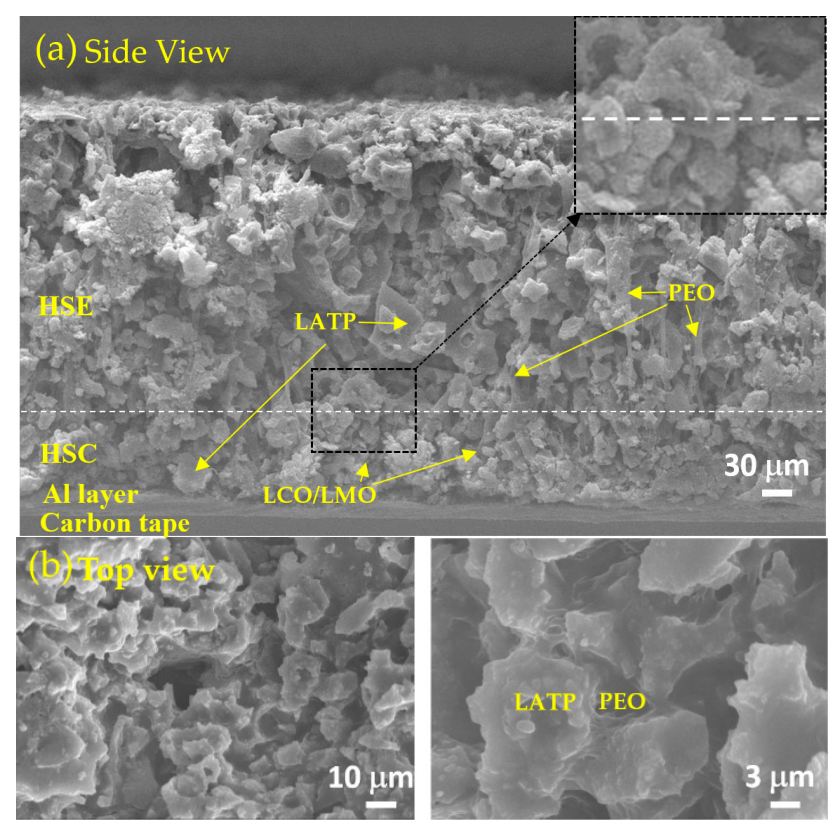

Figure 2. Cont. 

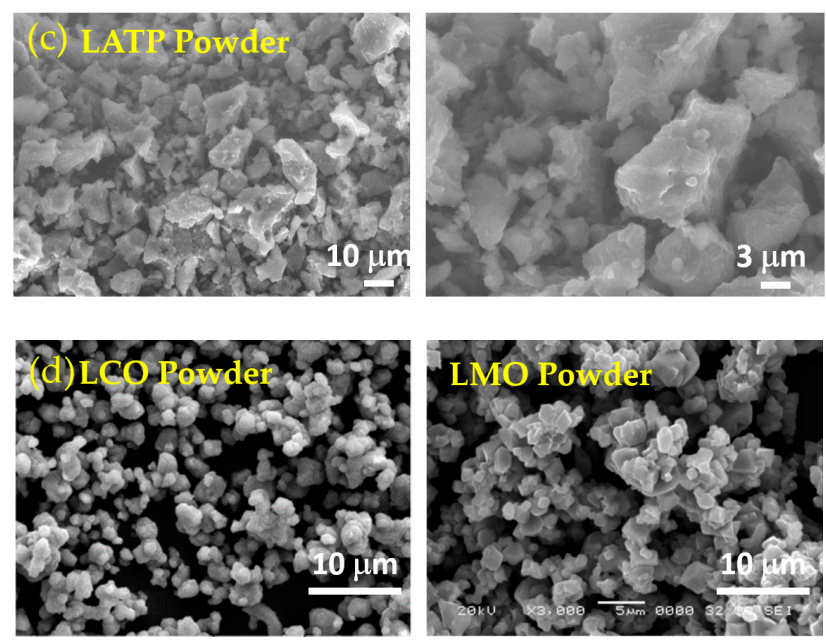

Figure 2. SEM images of (a) cross-section and (b) Top view of HSE-4/HSC-2/Al foil on carbon tape. SEM images of (c) LATP powder and (d) LCO and LMO powder. Scale bars in the images.

\subsection{Conductivity of the Designed Systems}

The total resistance is evaluated by ionic conductivity based on the electrochemical impedance spectroscopy (EIS) (Table 1). Using the measured resistance and following relation, ionic conductivity $(\sigma, \mathrm{S} / \mathrm{cm})$ of the designed HSE and HSC is evaluated,

$$
\sigma=\frac{1}{A \cdot S}
$$

where $l$ is the thickness $(\mathrm{cm})$ of the HSE, $A$ is the area $\left(\mathrm{cm}^{2}\right)$ of the sample, $S$ is the total resistance $(\Omega)$ obtained from EIS spectra. The ionic conductivity of the designed HSE shows almost three orders higher $\left(\sim 10^{-4} \mathrm{~S} / \mathrm{cm}\right)$ than that of pure PEO $\left(10^{-6} \sim 10^{-8} \mathrm{~S} / \mathrm{cm}\right)[50]$ at the same $\mathrm{EO}$ to $\mathrm{Li}(8: 1)$. This result confirms the contribution of high ionic conductivity of LATP embedded in the ion-conducting PEO by the reduced bulk and boundary resistance. Due to characteristic temperature-dependence, ionic conductivity at $55{ }^{\circ} \mathrm{C}$ is about 10 times higher than that at $23{ }^{\circ} \mathrm{C}$ in every sample. The composite system consisting of LiTFSI shows similar ionic conductivity as that using $\mathrm{LiPF}_{6}$. By adding $\mathrm{SN}$, ionic conductivities $\left(2.0 \times 10^{-4} \mathrm{~S} / \mathrm{cm} @ 23^{\circ} \mathrm{C} \& 1.6 \times 10^{-3} \mathrm{~S} / \mathrm{cm} @ 55{ }^{\circ} \mathrm{C}\right)$ are enhanced compared with those $\left(1.5 \times 10^{-4} \mathrm{~S} / \mathrm{cm} @ 23{ }^{\circ} \mathrm{C} \& 1.4 \times 10^{-3} \mathrm{~S} / \mathrm{cm} @ 55^{\circ} \mathrm{C}\right)$ without $\mathrm{SN}$ introduction by increased segmental mobility of PEO in HSE [40,51]. In particular, the increase in ionic conductivity by SN introduction is prominent at room temperature.

\subsection{Solid Electrolyte Interface (SEI)}

Even with several controversies the LATP and Li metal is reported to react immediately upon a physical contact and forms an unfavorable solid electrolyte interface (SEI) layer on the Li metal surface $[52,53]$. Through this unfavorable phenomenon $\mathrm{Li}$ ion movement is reduced, thus decreasing the ionic conductivity. However, this can be suppressed by surface modification using PEO coating. The role of PEO in HSE is, at the same context, surrounding each LATP particle to protect the Li metal surface. The efficacy of the designed HSE on Li metal anode is investigated by measuring the AC impedance (Figure 3c). The chemical reactions of the designed model cells symmetrically composed of $\mathrm{Li} / \mathrm{LATP}$ pellet/Li and $\mathrm{Li} / \mathrm{HSE} / \mathrm{Li}$ are evaluated for 25 days. The LATP pellet was made without sintering LATP powder after pressing. The experiment is performed to analyze the chemical reaction at the interface of LATP, HSE-1(PEO), HSE-4 and Li metal. Thus, the initial interfacial resistance of $\mathrm{Li} / \mathrm{LATP} / \mathrm{Li}$ symmetric cell was measured to be high. Among them, selected results of Li/LATP/Li, $\mathrm{Li} / \mathrm{HSE}-1 / \mathrm{Li}$ and $\mathrm{Li} / \mathrm{HSE}-4 / \mathrm{Li}$ are shown Figure $3 \mathrm{a}-\mathrm{c}$. The increase in the interfacial resistance has 
been observed in the system of LATP/Li metal [54] and PEO/Li metal by the characteristic chemical reactions [42].

(a)
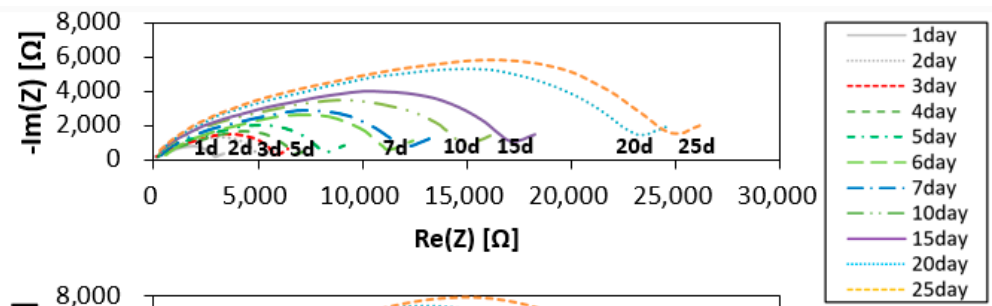

(b)

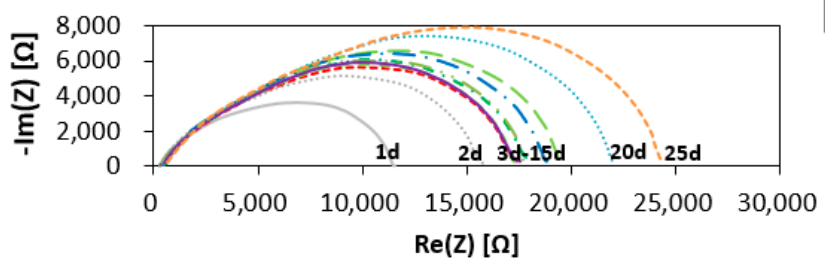

(c)

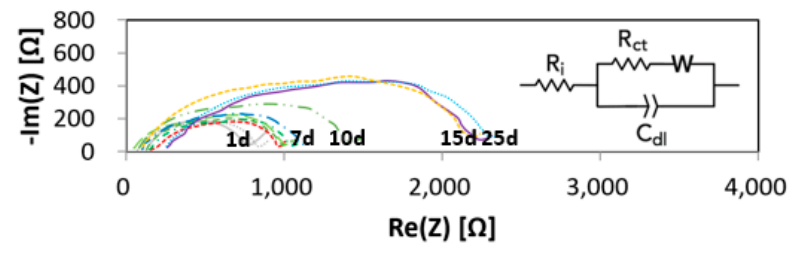

(d)

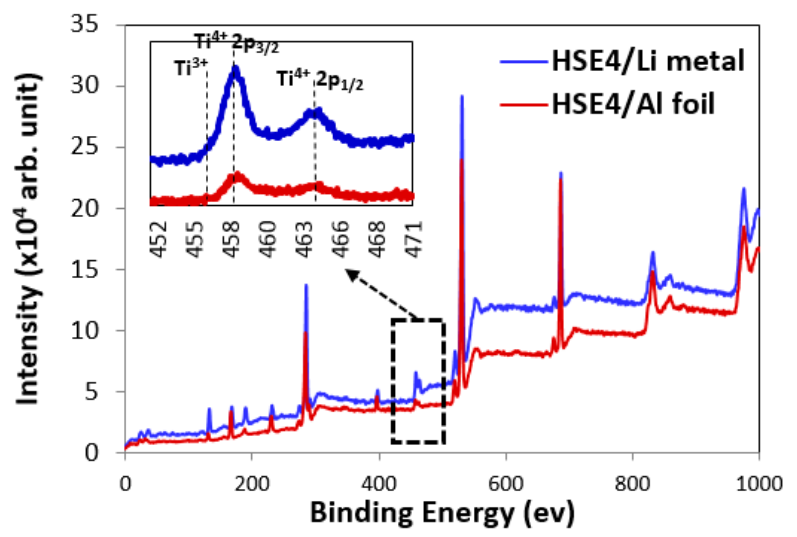

Figure 3. Impedance spectra of (a) Li/LATP/Li (b) Li/HSE-1/Li (c) $\mathrm{Li} / \mathrm{HSE}-4 / \mathrm{Li}$ symmetric cells during 25 days (d) Ti2 $\mathrm{p}_{3 / 2}$ and Ti2 $\mathrm{p}_{1 / 2}$ photoelectron signals of Ti films (HSE-4) coated on Li metal and $\mathrm{Al}$ foil for 25 days.

The interfacial resistance of the symmetric cells designed as $\mathrm{Li} / \mathrm{LATP} / \mathrm{Li}$ and $\mathrm{Li} / \mathrm{HSE}-1 / \mathrm{Li}$ continuously increase the interfacial resistance for 25 days. However, the resistance of the $\mathrm{Li} / \mathrm{HSE}-4 / \mathrm{Li}$ cell is almost similar at a low value for all 25 days (Figure 3c). The result suggests that the reaction of HSE-4 on Li metal is far more effective than that of LATP. An equivalent circuit to describe the observed AC impedance spectra is shown in the inset of Figure 3c, which represents a hybrid solid electrolyte sandwiched between two blocking electrodes. In this equivalent circuit, $R_{\mathrm{ct}}$ is the bulk resistance of the solid electrolyte, $C_{\mathrm{dl}}$ (constant phase element) denotes the bulk capacitance of the hybrid solid electrolyte, and Ri corresponds to the double layer capacitance at the electrode/electrolyte interface. Constant phase elements rather than capacitors were employed to describe non-idealities in AC impedance responses. The experimental data were fitted using the Randles equivalent circuit. Indeed, the AC impedance of a lithium metal symmetric cell is composed of the resistance at the electrolyte/electrode interface and the Ohmic resistance of the electrolyte itself.

In order to evaluate the impedance aforementioned result, X-ray photoelectron spectroscopy (XPS) measurements of the HSE samples are performed before and after the reaction with Li metals for 
25 days (Figure 3d). For this, Ti peaks of HSE-4 pasted on Li metal after aging procedures for 25 days (blue line) are compared with HSE-4 on Al foil, with the physical substrate (red line) employed as a standard. Doublet peaks consist of Ti $2 \mathrm{p}_{1 / 2}$ and Ti $2 \mathrm{p}_{3 / 2}$ : two strong $\mathrm{Ti}^{4+}$ peaks, i.e., $2 \mathrm{p}_{1 / 2}\left(\mathrm{Ti}^{4+}\right.$, $464.6 \mathrm{eV}$ ) and $2 \mathrm{p}_{3 / 2}$ oxide $\left(\mathrm{Ti}^{4+}, 458.8 \mathrm{eV}\right)$, two $\mathrm{Ti}^{3+}$ peaks (457 eV and $\left.463.1 \mathrm{eV}\right)$ [55].

Even with physical contact of HSE-4 with Li metal, the binding energy of two samples in this study is same. The resulting XPS has no difference where the Ti $2 \mathrm{p}_{1 / 2}$ and Ti $2 \mathrm{p}_{3 / 2}$ remain at the same energy position, indicating there is no Ti reduction (from $\mathrm{Ti}^{4+}$ to $\mathrm{Ti}^{3+}$ ) [54].

\subsection{Electrochemical Stability}

To investigate the electrochemical stability of each electrolyte layer, linear sweep voltammetry (LSV) was measured from 1.5 to $6 \mathrm{~V}$ for both reduction and oxidation procedures (Figure 4). The oxidative stability is measured from the open current voltage (OCV) by sweeping up the voltage, while the reduction is measured by sweeping down the voltage. In Figure 4, the voltage was swept from $\sim 2.2 \mathrm{~V}$ up to $6 \mathrm{~V}$ and then down again to $2.2 \mathrm{~V}$. Both electrolytes HSE-3 and HSE-4 clearly show an onset of oxidation around 4 and $3.4 \mathrm{~V}$, respectively. After going up to $6 \mathrm{~V}$, the electrolyte will be partially or completely decomposed. During the sweeping down from that stage, the reductive stability was measured in a separate experiment: $1.2 \mathrm{~mol} \mathrm{~L}^{-1} \mathrm{LiPF}_{6}$ in a 15:50:35 (in volume ratio) mixture of ethylene carbonate (EC) and ethyl methyl carbonate (EMC) and dimethyl carbonate (DMC) as the liquid electrolyte used as a standard contrast is oxidized at $4.8 \mathrm{~V}$ indicated by the sudden increase in the current (blue line). HSE (HSE-3) and HSE+SN (HSE-4) are also oxidized even if the absolute current intensity is relatively lower than that of liquid electrolyte. This electrochemical investigation of the designed cells indicates protective film formation on the cathode surface in the first cycle which works as a solid electrolyte interphase (SEI) in liquid electrolytes. On the other hand, during the reduction procedure of both HSE-3 and HSE-4, the current is very low without noticeable peak in all voltage regions observed in this study.

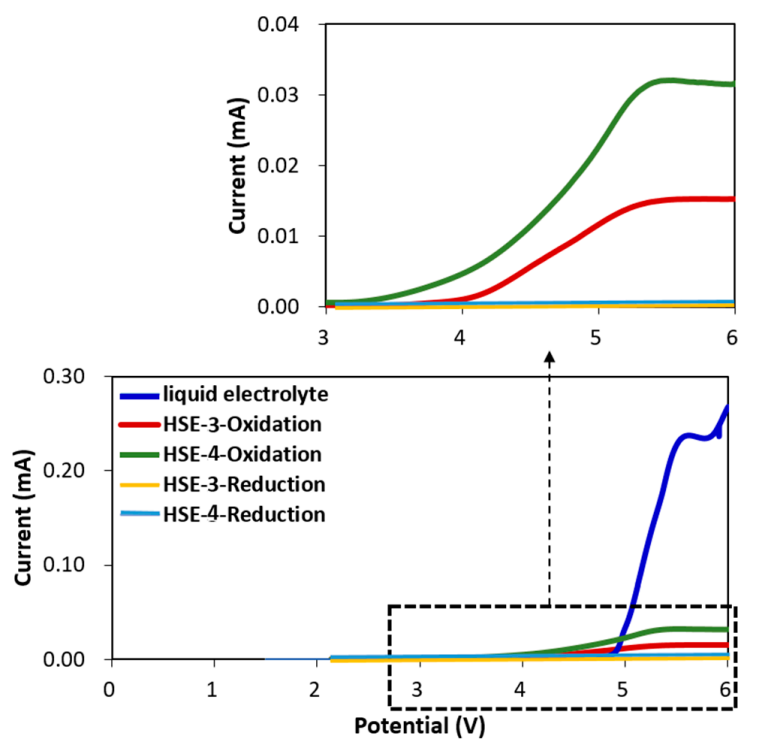

Figure 4. Linear sweep voltammetry (LSV) scans of HSE-3 and HSE-4. Pt is employed as a working electrode and Li metal is employed as reference electrodes. Scan rate is at the $1 \mathrm{mV} / \mathrm{s}$.

\subsection{Property of the Designed Electrolytes}

Due to inherent high boundary resistance, LATP hardly generates high ionic conductivity. A value of ca. $3.4 \times 10^{-3} \mathrm{~S} / \mathrm{cm}$ at $293 \mathrm{~K}$, is among the highest conductivities reported for LATP-based systems [56-58]. To overcome this disadvantage, PEO is employed in this study. The structure of the $\mathrm{PEO}$-incorporated system prepared on $\mathrm{Al}$ foil is investigated using $\mathrm{X}$-ray powder diffraction (XRD) 
in Figure 5a. The XRD patterns of LATP-incorporated systems are almost similar. XRD patterns of HSE films exhibit lower intensity by the polymer incorporation without peak broadening. With the $\mathrm{SN}$ incorporation, XRD peak intensity becomes far lower, indicating the dilution of the whole system. Nonetheless the lattice structure is effectively maintained.

The ionic conductivity and thermal characteristics are modified according to the molecular weight of the PEO, which changes from $1 \times 10^{5}, 3 \times 10^{5}$ to $6 \times 10^{5}$ in this study. The segmental mobility of $\mathrm{PEO}$ is investigated using differential scanning calorimetry (DSC) (Figure 5b). With the increase of PEO molecular weight, the peak temperature increases from $65.741{ }^{\circ} \mathrm{C}\left(\mathrm{PEO} \mathrm{M}_{\mathrm{W}}=1 \times 10^{5}\right), 67.663{ }^{\circ} \mathrm{C}$ $\left(\mathrm{PEO} M_{\mathrm{W}}=3 \times 10^{5}\right)$ and $68.157^{\circ} \mathrm{C}\left(\mathrm{PEO} M_{\mathrm{W}}=6 \times 10^{5}\right)$. In addition, the magnitude of the heat density decreases from $178.31 \mathrm{~J} / \mathrm{g}, 172.41 \mathrm{~J} / \mathrm{g}$ to $170.87 \mathrm{~J} / \mathrm{g}$. However, the designed HSE systems with LATP and SN do not generate characteristic peaks at the given condition in Figure $5 \mathrm{c}$. This indicates that incorporation of LATP and SN effectively broadens the amorphous state to the wide temperature ranges, increasing the ionic conductivity under that condition. The DSC result of the system consisting of LiTFSI has been verified to become amorphous when the ratio of the [EO]/[Li] is higher than ten [59]. In this study, the system consisted of LiTFSI with the ratio [EO]/[Li] $=8$ exhibits an amorphous phase with the help of SN introduction. Based on this ionic conductivity result, the system with higher molecular weight PEO $M_{\mathrm{W}}=6 \times 10^{5}$ is selected to obtain the enhanced mechanical property for the design of HSE, while lower molecular weight PEO $M_{\mathrm{W}}=3 \times 10^{5}$ is employed for better mixing efficacy to design the cathode electrode.
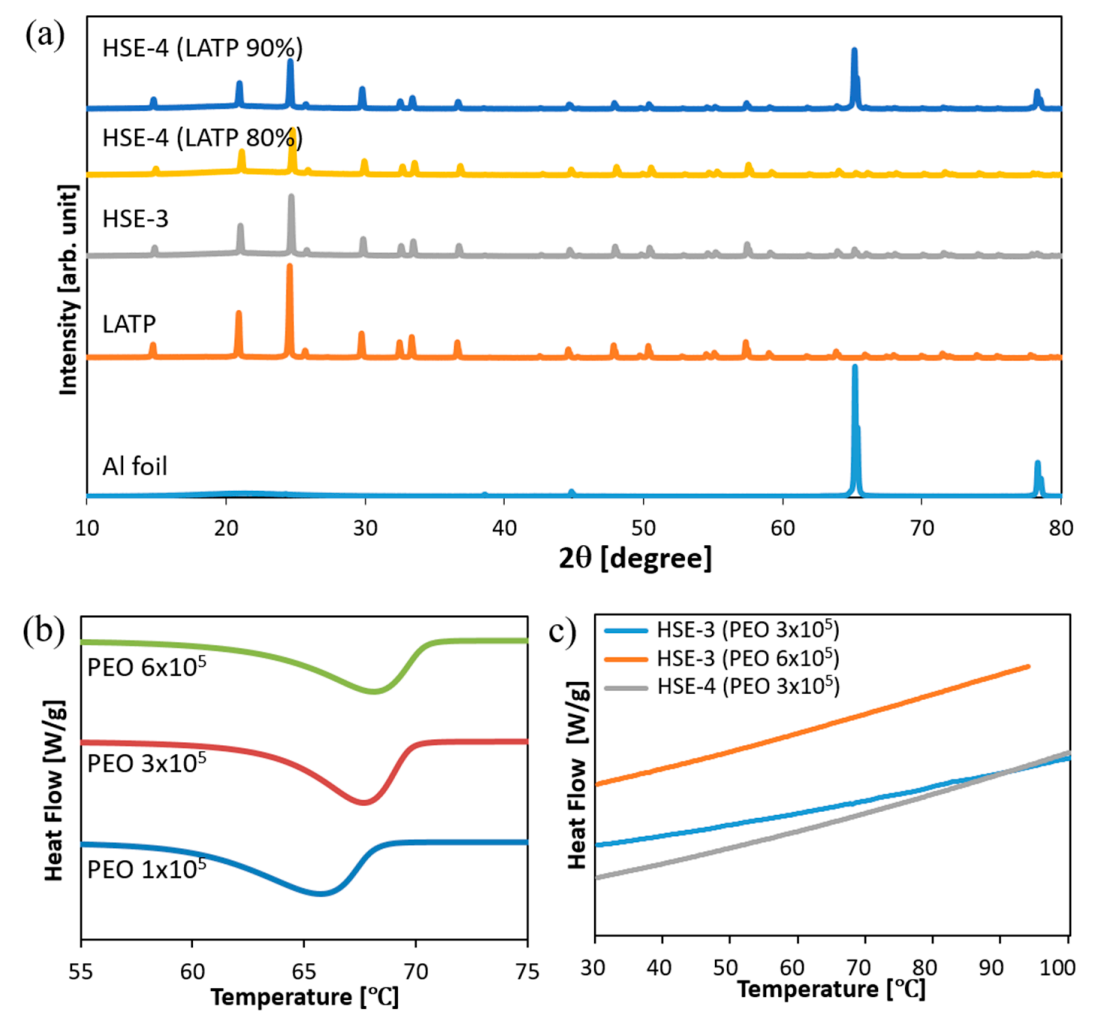

Figure 5. (a) XRD Patterns of LATP, HSE-3, HSE-4 (b) DSC of PEO with different molecular weight $1 \times$ $10^{5}, 3 \times 10^{5}$ and $6 \times 10^{5}(\mathrm{c})$ DSC of HSE-3 $\left(\right.$ PEO $\left.3 \times 10^{5}\right)$, HSE-3 $\left(\right.$ PEO $\left.6 \times 10^{5}\right)$ and HSE-4 (PEO $3 \times$ $10^{5}$ ) composed of each PEO.

\subsection{Capacity and 1st Coulomb Efficiency of the Designed Coin Cells}

Figure 6a shows specific capacity-voltage curves of the first charge-discharge cycles of the selected model cell systems. The 1st cyclic profiles of the LCO-LMO/HSE/Li system for each designed HSC-1/HSE-2/Li, HSC-1/HSE-3/Li and HSC-1/HSE-4/Li and HSC-2/HSE-4/Li are compared at $55{ }^{\circ} \mathrm{C}$. The HSC-1/HSE-2/Li curve has more polarization loss compared to other 
curves. Further, the plateau region is quite broader for three other cases compared to the discharge curve of HSC-1/HSE-2/Li in terms of the slope nature. Although the difference is small in all the systems, the result of HSC-1/HSE-2/Li shows slight a disadvantage compared to the three other systems. Electrochemical Impedance Spectroscopy (EIS) results at $55^{\circ} \mathrm{C}$ (Figure $6 \mathrm{~b}$ ) and room temperature (Figure 6c) are shown. $\mathrm{LiPF}_{6}$ is generally used for liquid electrolytes, while $\mathrm{LiClO}_{4}$ and LiTFSI are favorably employed for solid electrolyte systems. The ionic conductivity of the designed HSE is not so different (Table 1) but the resistance and charge-discharge efficacy in the designed Li ion cell are very different. $\mathrm{LiPF}_{6}$ (HSC-1/HSE-2/Li) and LiTFSI (HSC-1/HSE-3/Li, HSC-1/HSE-4/Li\& HSC-2/HSE-4/Li) are used with PEO in this study, in which the physical properties of HSC-1/HSE-2/Li are different from other three systems.

(a)

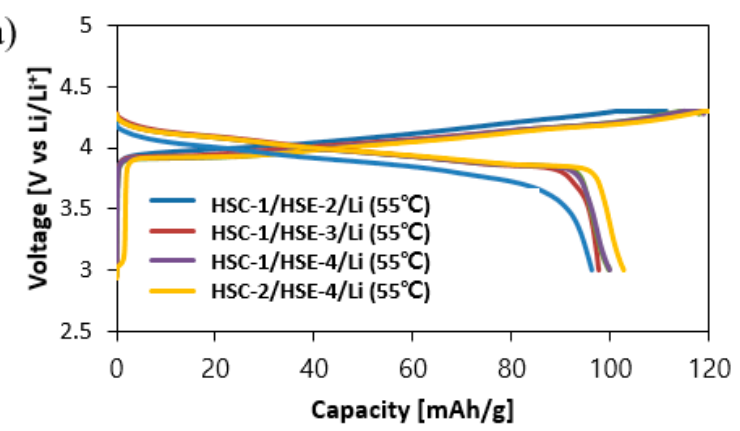

(b)
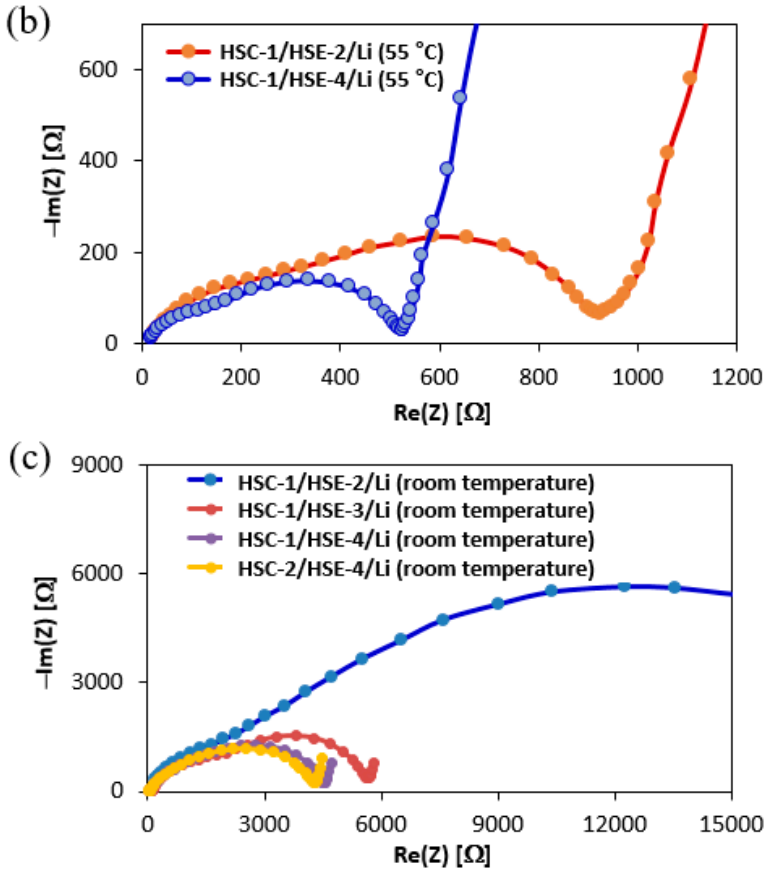

Figure 6. (a) 1st charge-discharge profiles of HSC-1/HSE-2/Li, HSC-1/HSE-3/Li, HSC-1/HSE-4/Li and HSC-2/HSE-4/Li at $55{ }^{\circ} \mathrm{C}$. EIS profiles of (b) HSC-1/HSE-2/Li and HSC-1/HSE-4/Li at $55{ }^{\circ} \mathrm{C}$ and (c) HSC-1/HSE-2/Li, HSC-1/HSE-3/Li, HSC-1/HSE-4/Li and HSC-2/HSE-4/Li at room temperature.

However, for $\mathrm{LiPF}_{6}$ (HSC-1/HSE-2/Li for this study) and LiTFSI incorporated systems (HSC-1/HSE-4/Li for this study), the resistance of the system in actual Li ion cell state doubles at $55^{\circ} \mathrm{C}$ and $\mathrm{LiPF}_{6}$ (HSC-1/HSE-2/Li in this study) and in LiTFSI incorporated systems (HSC-1/HSE-3/Li for this study); the resistance of the system in the actual $\mathrm{Li}$ ion cell state increases four-fold compared with that at room temperature. In the Li ion cell state, the re-crystallization kinetics of PEO has been effectively slowed by the use of Li ions and bulky anions [60]. The moisture generated by the electrode-cooling, decomposes $\mathrm{LiPF}_{6}$ into $\mathrm{PF}_{5}$, leading to the resistance increase by the interaction 
between PEO and SEI [61]. Through this effect, in addition to overcharging, the constant voltage region becomes broader during the charging process while capacity decreases during the discharging procedure. When moisture-resistant LiTFSI or LiTFSI+SN are used, aforementioned phenomena are reduced and capacity can be increased. In the system composed of LiTFSI+SN (HSE-4), SN promotes the Li ion dissolution, thus capacity increases far higher than that of LiTFSI-only (HSE-3). The charging-discharging process occurring at room temperature also shows similar results for the three systems while the HSC-1/HSE-2/Li composed of $\mathrm{LiPF}_{6}$ exhibits a dramatic difference. This result indicates that the moisture formation after the cooling procedure turns the $\mathrm{LiPF}_{6}$ into $\mathrm{PF}_{6}$ gas and SEI in PEO, where SEI decreases the efficiency of the battery function significantly.

The Li ion transport resistance in the HSE system is determined by its through-plane resistance instead of the ionic conductivity. The actual $\mathrm{Li}$ ion transport resistance may increase with increasing HSE thickness [62]. The designed HSEs in this study are the same thickness. Therefore, the higher conductivity of HSE+SN(HSE-4) ensures excellent Li ion transport performance. This is due to higher ionic conductivity of HSE-4 than HSE-3 and HSE-4 (Table 1), and the reduced resistance of a designed system even with the same thickness (Figure 6c).

Figure 7a displays 1st charge-discharge profiles of the LCO-LMO/electrolyte/Li metal systems of selected HSC-1/HSE-4/Li and HSC-2/HSE-4/Li (both are based on LiTFSI+SN composition) at room temperature. This indicates that $\mathrm{SN}$ addition boosts the battery function compared with the cells employing $\mathrm{LiPF}_{6}$ (HSC-1/HSE-2/Li) and LiTFSI-only (HSC-1/HSE-3/Li), which are not working effectively at room temperature. The difference is clearer by the $\mathrm{C}$-rate performance at $55{ }^{\circ} \mathrm{C}$ (Figure $7 \mathrm{~b}$ ). The $\mathrm{C}$-rate values of each region are on the graph: $0.05 \mathrm{C}, 0.1 \mathrm{C}, 0.2 \mathrm{C}, 0.5 \mathrm{C}$, and $0.05 \mathrm{C}$. At the 1st charging procedure, the capacity of each cell is $111.4 \mathrm{mAh} / \mathrm{g}$ (HSE-2), 118.5 $\mathrm{mAh} / \mathrm{g}$ (HSE-3), $118.9 \mathrm{mAh} / \mathrm{g}$ (HSE-4), and $123.4 \mathrm{mAh} / \mathrm{g}$ (HSC-2), while at the discharging procedure, it is $96.2 \mathrm{mAh} / \mathrm{g}, 97.6 \mathrm{mAh} / \mathrm{g}, 99.9 \mathrm{mAh} / \mathrm{g}$, and $102.7 \mathrm{mAh} / \mathrm{g}$, respectively. At the initial formation, Coulombic efficiency was $86.4 \%, 82.3 \%, 84.0 \%$, and $83.2 \%$, respectively, based on the ratio of discharged capacity to charged capacity. In addition, their Coulombic efficiency increases continuously and is stabilized. After the initial cyclic repetition, the overall cyclic repetition over the $99 \%$ is maintained. After 20 cycles, it is also maintained by the charging-recharging at $0.05 \mathrm{C}$.
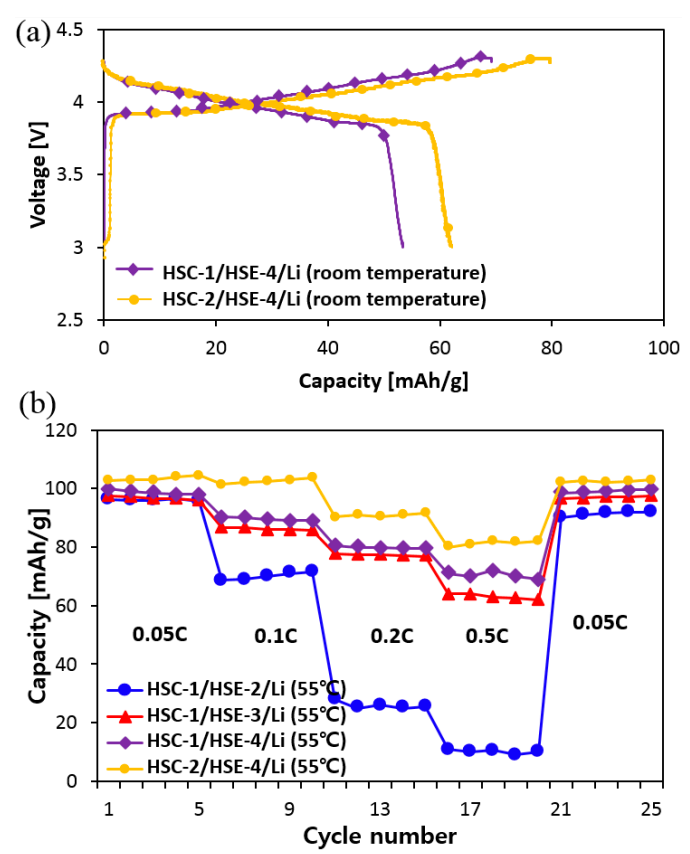

Figure 7. (a) 1st charge-discharge profiles of HSC-1/HSE-4/Li cell and HSC-2/HSE-4/Li cell at room temperature. (b) C-rate performance of HSC-1/HSE-2, HSE-3, HSE-4/Li cells and HSC-2/HSE-4/Li cell at $55^{\circ} \mathrm{C}$. 


\section{Discussion and Conclusions}

In this study, hybrid solid electrolytes (HSEs) composed of LATP, PEO and SN are successfully designed without protection layer introduction. The solid electrolyte, LATP interaction with Li ion, promotes the reduction of $\mathrm{Ti}^{4+}$ into $\mathrm{Ti}^{3+}$. The LATP shows ion conductivity of $3 \times 10^{-3} \mathrm{~S} / \mathrm{cm}$ under the state of $\mathrm{Ti}^{4+}$ but it becomes far lower under the state of $\mathrm{Ti}^{3+}$ due to structural deformation affecting Li ion movement [11]. We observed no reduction of $\mathrm{Ti}^{4+}$ into $\mathrm{Ti}^{3}$ in the designed system which is investigated by Electrochemical Impedance Spectroscopy (EIS) and X-ray photoelectron spectroscopy (XPS).

In addition to the new hybrid solid electrolyte (HSE), new hybrid solid cathodes (HSCs) are designed and investigated, composed of LATP, PEO, LiTFSi and SN. Typically employed for mass-production, slurry casting methods are utilized followed by lamination to reduce contact resistance. In addition, during the dynamic charge-discharge procedure of the designed Li ion cells, the effects of internal resistance on the charge-discharge procedure and $\mathrm{C}$-rate changes are investigated. The interfacial resistance of HSE-4/Li metal symmetric cell is greatly improved compared with the LATP/Li metal symmetric cell (Figure 3). This suggests that the solution casting process and lamination introduced in this study lower the contact resistance between the Li metal and HSE-4. With good cycling stability, the designed cell also exhibits reasonable interfacial contact efficiency with electrode.

We suggest the new electrolyte system is advantageously utilized in all solid-state Li batteries. Even without any protection layer, the designed system shows no reduction of Ti. This study contributes to a new design technology and further possible mass-production of all solid-state $\mathrm{Li}$ batteries in more economical and effective ways.

Author Contributions: Data curation, S.C. and S.A.; Formal analysis, S.C. and S.A.; Funding acquisition, S.C.; Writing—original draft, S.C. and S.A.; Writing—review \& editing, S.K. (Shinho Kim), W.K., S.K. (Seok Kim) and S.A.

Acknowledgments: This research was supported by the Industrial Fundamental Technology Development Program (10052745, Development of the nano-sized $(100 \mathrm{~nm})$ manganese ceramic material for high voltage pseudo-capacitor) funded by the Ministry of Trade, Industry and Energy (MOTIE) of Korea.

Conflicts of Interest: The authors declare no competing interests.

\section{References}

1. Nazri, A. Lithium Batteries Science and Technology; Kluwer Academic Publishers: New York, NY, USA, 2009.

2. Wang, Q.; Ping, P.; Zhao, X.; Chu, G.; Sun, J.; Chen, C. Thermal runaway caused fire and explosion of lithium ion battery. J. Power Sources 2012, 208, 210-224. [CrossRef]

3. Santhanagopalan, S.; Ramadass, P.; Zhang, J. Analysis of internal short-circuit in a lithium ion cell. J. Power Sources 2009, 194, 550-557. [CrossRef]

4. Armand, M.; Tarascon, J.M. Building better batteries. Nature 2008, 451, 652-657. [CrossRef] [PubMed]

5. Wakihara, M.; Kadoma, Y.; Kumagai, N.; Mita, H.; Araki, R.; Ozawa, K.; Ozawa, Y. Development of nonflammable lithium ion battery using a new all-solid polymer electrolyte. J. Solid State Electrochem. 2012, 16, 847-855. [CrossRef]

6. Goodenough, J.B. Ceramic solid electrolytes. Solid State Ion. 1997, 94, 17-25. [CrossRef]

7. Knauth, P. Inorganic solid Li ion conductors: An overview. Solid State Ion. 2009, 180, 911-916. [CrossRef]

8. Xu, K. Nanoqueous Liquid Electrolytes for Lithium-Based Rechargeable Batteries. Chem. Rev. 2004, 104, 4303-4418. [CrossRef]

9. Goodenough, J.B.; Kim, Y. Challenges for rechargeable batteries. J. Power Sources 2011, 196, 6688-6694. [CrossRef]

10. Fergus, W.J. Ceramic and polymeric solid electrolytes for lithium-ion batteries. J. Power Sources 2010, 195, 4554-4569. [CrossRef]

11. Tanaka, K. Lithium ion conduction in $\mathrm{LiTi}_{2}\left(\mathrm{PO}_{4}\right)_{3}$. J. Electrochem. Acta 2014, 133, 529-538.

12. Park, C.G. Lithium bis(fluorosulfonyl)imide/poly(ethylene oxide)polymer electrolyte. In Principles and Applications of Lithium Secondary Batteries; Hongpub: Seoul, Korea, 2010; pp. 327-328. 
13. Tong, Y.; Lyu, H.; Xu, Y.; Bishnu, P.T.; Li, P.; Xiao, G.S.; Sheng, D. All-solid-state interpenetrating network polymer electrolytes for long cycle life of lithium metal batteries. J. Mater. Chem. A 2018, 6, 14847-14855. [CrossRef]

14. Zeng, X.X.; Yin, Y.X.; Li, N.W.; Du, W.C.; Guo, Y.G.; Wan, L.J. Reshaping Lithium Plating/Stripping Behavior via Bifunctional Electrolyte for Room Temperature Solid Li Metal Batteries. J. Am. Chem. Soc. 2016, 138, 15825-15828. [CrossRef] [PubMed]

15. Li, J.; Ma, C.; Chi, M.; Liang, C.; Dudney, N. Solid electrolyte: The key for high-voltage lithium batteries. Adv. Energy Mater. 2015, 5, 1401408. [CrossRef]

16. Bachman, J.C.L.; Muy, S.; Grimaud, A.; Chang, H.; Pour, N. Inorganic solid-state electrolytes for lithium batteries: Mechanisms and properties governing ion conduction. Chem. Rev. 2015, 116, 140-162. [CrossRef] [PubMed]

17. Xiayin, Y. All-solid-state lithium batteries with inorganic solid electrolytes: Review of fundamental science. Chin. Phys. 2016, B25, 018802.

18. Goodenough, J.B.; Singh, P. Review-Solid electrolytes in rechargeable electrochemical cells. J. Electrochem. Soc. 2015, 162, A2387-A2392. [CrossRef]

19. Janek, J.; Zeier, W.G. A solid future for battery development. Nat. Energy 2016, 1, 16141. [CrossRef]

20. Porcarelli, L.; Shaplov, A.S.; Salsamendi, M.; Nair, J.R.; Vygodskii, Y.S.; Mecerreyes, D.; Gerbaldi, C. Single-Ion Block Copoly(ionic liquid)s as Electrolytes for All-Solid State Lithium Batteries. ACS Appl. Mater. Interfaces 2016, 8, 10350-10359. [CrossRef]

21. Porcarelli, L.; Aboudzadeh, M.; Rubatat, L.; Nair, J.R.; Shaplovde, A.S.; Gerbaldib, C.; Mecerreyesa, D. Single-ion triblock copolymer electrolytes based on poly(ethylene oxide) and methacrylic sulfonamide blocks for lithium metal batteries. J. Power Sources 2017, 364, 191-199. [CrossRef]

22. Porcarelli, L.; Manojkumar, K.; Sardon, H.; Llorente, O.; Shaplovde, A.S.; Gerbaldi, C.; Vijayakrishna, K.; Mecerreyes, D. Single ion conducting polymer electrolytes based on versatile polyurethanes. Electrochim. Acta 2017, 241, 526-534. [CrossRef]

23. Porcarelli, L.; Gerbaldi, C.; Bella, F.; Nair, J.R. Super soft all-ethylene oxide polymer electrolyte for safe all-solid lithium batteries. Sci. Rep. 2016, 6, 19892. [CrossRef] [PubMed]

24. MacCallum, J. Polymer Electrolyte Reviews-1; Elsevier Applied Science: London, UK; New York, NY, USA, 1987.

25. Bailey, F.E., Jr.; Koleske, J.V. Poly(ethylene oxide); Academic Press: New York, NY, USA, 1976.

26. Wright, P.V. Electrical conductivity in ionic complexes of poly(ethylene oxide). Polym. Int. 1975, 7, 319-327. [CrossRef]

27. Fenton, D.E. Complexes of alkali metal ions with poly(ethylene oxide). Polymer 1973, 14, 589. [CrossRef]

28. Armmd, M.B. Polymer solid electrolytes-An overview. Solid State Ion. 1983, 9-10, 745-754. [CrossRef]

29. Ryu, S.W.; Trapa, P.E.; Olugebefola, S.C.; Gonzalez-Leon, J.A.; Sadoway, D.R.; Mayes, A.M. Effect of counter ion placement on conductivity in single-ion conducting block copolymer electrolytes. J. Electrochem. Soc. 2005, 152, A158-A163. [CrossRef]

30. Kang, W.C.; Park, H.G.; Kim, K.C.; Ryu, S.W. Synthesis and electrochemical properties of lithium methacrylate-based self-doped gel polymer electrolytes. Electrochim. Acta 2009, 54, 4540-4544. [CrossRef]

31. Bruce, P.G.; Vincent, C.A. Steady state current flow in solid binary electrolyte cells. J. Electroanal. Chem. Interfacial Electrochemchem. 1987, 225, 1-17. [CrossRef]

32. Kroka, F.; Dygasa, J.R.; Misztal-Faraja, B.; Florjańczyk, Z.; Bzducha, W. Impedance and polarization studies of new lithium polyelectrolyte gels. J. Power Sources 1999, 81, 766-771. [CrossRef]

33. Stramare, S.; Weppner, W. Structure and conductivity of B-site substituted (Li,La)TiO $\mathrm{Ti}_{3}$ Mater. Sci. Eng. 2004, B113, 85-90. [CrossRef]

34. Murugan, R.; Thangadurai, V.; Weppner, W. Fast Lithium Ion Conduction in Garnet-Type $\mathrm{Li}_{7} \mathrm{La}_{3} \mathrm{Zr}_{2} \mathrm{O}_{12}$. Angew. Chem. 2007, 46, 7778-7781. [CrossRef]

35. Hanc, E.Z.; Molenda, J. Fast Lithium Ion Conduction in Garnet-Type $\mathrm{Li}_{7} \mathrm{La}_{3} \mathrm{Zr}_{2} \mathrm{O}_{12}$. Solid State Ion. 2014, 262, 617-621. [CrossRef]

36. Aono, H.; Sugimoto, E.; Sadaoka, Y.; Imanaka, N.; Adachi, G.J. Ionic Conductivity of Solid Electrolytes Based on Lithium Titanium Phosphate. Electrochem. Soc. 1990, 137, 1023-1027. [CrossRef]

37. Kato, Y. Discharge Performance of All-Solid-State Battery Using a Lithium Superionic Conductor $\mathrm{Li}_{10}$ $\mathrm{GeP}_{2} \mathrm{~S}_{12}$. Electrochemtry 2012, 10, 749-751. [CrossRef] 
38. Wang, C.; Yang, Y.; Liu, X.; Zhong, H.; Xu, H.; Xu, Z.; Shao, H. Suppression of Lithium Dendrite Formation by Using LAGP-PEO (LiTFSI) Composite Solid Electrolyte and Lithium Metal Anode Modified by PEO (LiTFSI) in All-Solid-State Lithium Batteries. ACS Appl. Mater. Interfaces 2017, 9, 13694-13702. [CrossRef] [PubMed]

39. Han, X.; Gong, Y.; Fu, K.; He, X.; Hitz, G.T.; Pearse, A.; Liu, B.; Wang, H.; Rubloff, G.; Mo, Y.; et al. Negating interfacial impedance in garnet-based solid-state Li metal batteries. Nat. Mater. 2017, 16, 572-579. [CrossRef] [PubMed]

40. Jung, Y.C.; Lee, S.M.; Choi, J.H.; Jang, S.S.; Kim, D.W. All Solid-State Lithium Batteries Assembled with Hybrid Solid Electrolytes. J. Electrochem. Soc. 2015, 162, A704-A710. [CrossRef]

41. Liu, W.; Milcarek, R.J.; Falkenstein-Smith, R.L.; Ahn, J. Interfacial Impedance Studies of Multilayer Structured Electrolyte Fabricated With Solvent-Casted $\mathrm{PEO}_{10}-\mathrm{LiN}\left(\mathrm{CF}_{3} \mathrm{SO}_{2}\right)_{2}$ and Ceramic $\mathrm{Li}_{1.3} \mathrm{Al}_{0.3} \mathrm{Ti}_{1.7}\left(\mathrm{PO}_{4}\right)_{3}$ and Its Application in All-Solid-State Lithium Ion Batteries. Electrochem. Energy Convers. Storage 2016, 13, 021008. [CrossRef]

42. Zhao, Y.; Wu, C.; Peng, G.; Chen, X.; Yao, X.; Bai, Y.; Wu, F.; Chen, S.; Xu, X. A new solid polymer electrolyte incorporating $\mathrm{Li}_{10} \mathrm{GeP}_{2} \mathrm{~S}_{12}$ into a polyethylene oxide matrix for all-solid-state lithium batteries. J. Power Sources 2016, 301, 47-53. [CrossRef]

43. Chen, B.; Huang, Z.; Chen, Z.; Zhao, Y.; Xu, Q.; Peng, L.; Chen, S.; Xu, X. A new composite solid electrolyte $\mathrm{PEO} / \mathrm{Li}_{10} \mathrm{GeP}_{2} \mathrm{~S}_{12} / \mathrm{SN}$ for all-solid-state lithium battery. Electrochim. Acta 2016, 210, 905-914. [CrossRef]

44. Long, S.; Macfarlane, D.R.; Forsyth, M. Fast ion conduction in molecular plastic crystals. Solid State Ion. 2003, 161, 105-112. [CrossRef]

45. Alarco, P.J.; Abu-Lebdeh, Y.; Armand, M. Highly conductive, organic plastic crystals based on pyrazolium imides. Solid State Ion. 2004, 175, 717-720. [CrossRef]

46. Ohtomo, T.; Hayashi, A.; Tatsumisago, M.; Kawamoto, K. Suppression of $\mathrm{H}_{2} \mathrm{~S}$ gas generation from the $75 \mathrm{Li}_{2} \mathrm{~S}$ center dot $25 \mathrm{P}_{2} \mathrm{~S}_{5}$ glass electrolyte by additives. J. Mater. Sci. 2013, 48, 4137-4142. [CrossRef]

47. Jung, Y.C.; Park, M.S.; Doh, C.H.; Kim, D.W. Organic-inorganic hybrid solid electrolytes for solid-state lithium cells operating at room temperature. Electrochim. Acta. 2016, 218, 271-277. [CrossRef]

48. Tatsumisago, M.; Nagao, M.; Hayashi, A. Recent development of sulfide solid electrolytes and interfacial modification for all-solid-state rechargeable lithium batteries. J. Asian Ceram. Soc. 2013, 1, 17-25. [CrossRef]

49. Kim, J.G.; Son, B.; Mukherjee, S.; Schuppert, N.; Bates, A.; Kwon, O.; Choi, M.J.; Chung, H.Y.; Park, S. A review of lithium and non-lithium based solid state batteries. J. Power Sources 2015, 282, 299-322. [CrossRef]

50. Golodnitsky, D.; Strauss, E.; Peled, E.; Greenbaum, S. Review-On Order and Disorder in Polymer Electrolytes. J. Electrochem. Soc. 2015, 162, A2551-A2566. [CrossRef]

51. Kim, S.K.; Jung, Y.C.; Kim, D.H.; Shin, W.C.; Ue, M.; Kim, D.W. Lithium-Ion Cells Assembled with Flexible Hybrid Membrane Containing $\mathrm{Li}^{+}$-Conducting Lithium Aluminum Germanium Phosphate. J. Electrochem. Soc. 2016, 163, A974-A980. [CrossRef]

52. Camacho-Forero, L.E.; Smith, S.; Bertolini, T.W.; Balbuena, P.B. Reactivity at the Lithium-Metal Anode Surface of Lithium-Sulfur Batteries. J. Phys. Chem. C 2015, 119, 26828-26839. [CrossRef]

53. Lin, D.; Liu, Y.; Cui, Y. Reviving the lithium metal anode for high-energy batteries. Nat. Nanotechnol. 2017, 12, 194-206. [CrossRef]

54. Hartmann, P.; Leichtweiss, T.; Busche, M.R.; Schneider, M.; Reich, M.; Sann, J.; Adelhelm, P.; Janek, J. Degradation of NASICON-Type Materials in Contact with Lithium Metal: Formation of Mixed Conducting Interphases (MCI) on Solid Electrolytes. J. Phys. Chem. 2013, C117, 21064-21074. [CrossRef]

55. Fu, Y.; Du, H.; Zhang, S.; Huang, W. XPS characterization of surface and interfacial structure ofsputtered TiNi films on Si substrate. Mater. Sci. Eng. 2005, A403, 25-31. [CrossRef]

56. Marinado, T.; Hahlin, M.; Jiang, X.; Quintana, M.; Johanesson, E.M.J.; Gabrielsson, E.; Plogmaker, S.; Hagberg, D.P.; Boschloo, G.; Zakeeruddin, S.M.; et al. Surface Molecular Quantification and Photoelectrochemical Characterization of Mixed Organic Dye and Coadsorbent Layers on $\mathrm{TiO}_{2}$ for Dye-Sensitized Solar Cells. J. Phys. Chem. 2010, C114, 11903-11910. [CrossRef]

57. Campbell, J.L.; Rapp, T. Widths of the atomic K-N7 levels. In Atomic Data and Nuclear Data Tables; Elsevier: New York, NY, USA, 2001; Volume 77, pp. 1-56. [CrossRef]

58. Takahashi, K.; Ohmura, J.; Im, D.; Lee, D.J.; Zhang, T.; Imanishi, N.; Hirano, A.; Phillipps, M.B.; Takeda, Y.; Yamamoto, O. A Super High Lithium Ion Conducting Solid Electrolyte of Grain Boundary Modified $\mathrm{Li}_{1.4} \mathrm{Ti}_{1.6} \mathrm{Al}_{0.4}\left(\mathrm{PO}_{4}\right)_{3}$. J. Electrochem. Soc. 2012, 159, A342-A348. [CrossRef] 
59. Geiculescu, O.E.; Rajagopal, R.; Creager, S.E.; DesMarteau, D.D.; Zhang, X.; Fedkiw, P. Transport Properties of Solid Polymer Electrolytes Prepared from Oligomeric Fluorosulfonimide Lithium Salts Dissolved in High Molecular Weight Poly(ethylene oxide). J. Phys. Chem. B 2006, 110, 23130-23135. [CrossRef] [PubMed]

60. Vallee, A.; Besner, S.; PrudHomme, J. Comparative study of poly(ethylene oxide) electrolytes made with $\mathrm{LiN}\left(\mathrm{CF}_{3} \mathrm{SO}_{2}\right)_{2}, \mathrm{LiCF}_{3} \mathrm{SO}_{3}$ and $\mathrm{LiClO}_{4}$ : Thermal properties and conductivity behavior. Electrochem. Acta 1992, 37, 1579-1583. [CrossRef]

61. Sloop, S.E.; Kerr, J.B.; Kinoshita, K. The role of Li-ion battery electrolyte reactivity in performance decline and self-discharge. J. Power Sources 2003, 119, 330-337. [CrossRef]

62. Xiang, Y.; Wang, Z.; Qiu, W.; Guo, Z.; Liu, D.; Qu, D.; Xie, Z.; Tang, H.; Li, J. Interfacing soluble polysulfides with a $\mathrm{SnO}_{2}$ functionalized separator: An efficient approach for improving performance of Li-S battery. J. Memb. Sci. 2018, 563, 380-387. [CrossRef]

(C) 2018 by the authors. Licensee MDPI, Basel, Switzerland. This article is an open access article distributed under the terms and conditions of the Creative Commons Attribution (CC BY) license (http://creativecommons.org/licenses/by/4.0/). 